Article

\title{
Dasybranchus geojedoensis sp. nov. (Annelida: Capitellidae), a New Capitellid Species from Southern Korea
}

\author{
Man-Ki Jeong ${ }^{1}$ and Ho Young Soh ${ }^{1,2, *}$ \\ 1 Fishery Resource Management Research Institute based on ICT, Chonnam National University, \\ Daehak-ro 50, Yeosu 59626, Korea; jmgdeux@gmail.com \\ 2 Ocean Integrated Science, Chonnam National University, Daehak-ro 50, Yeosu 59626, Korea \\ * Correspondence: hysoh@chonnam.ac.kr
}

LSID: urn:lsid:zoobank.org:pub:2F56F5F2-CB66-44F4-B606-C08967B1472D

(http://zoobank.org/References/2F56F5F2-CB66-44F4-B606-C08967B1472D)

updates

Received: 3 July 2020; Accepted: 21 July 2020; Published: 24 July 2020

\begin{abstract}
Dasybranchus geojedoensis sp. nov., obtained from the soft sublittoral bottom in southern Korea, is described as a new species. This new species of Dasybranchus is easily distinguishable from its congeners by the protruded parapodial lobes in the final few thoracic chaetigers. Dasybranchus geojedoensis sp. nov. closely resembles D. bipartitus (Schmarda, 1861) in number and position of abdominal branchiae but differs in position of genital pores and lateral organs, range of thoracic tessellated chaetigers, and denticulation of the abdominal hooks. The partial mtCOI gene sequences of the new Korean species were significantly distinct from those of undescribed species of Dasybranchus from Australia. In this study, a key for known species of Dasybranchus is also provided.
\end{abstract}

Keywords: histone H3; methyl green staining; morphology; mtCOI; polychaete

\section{Introduction}

The polychaetes belonging to Dasybranchus Grube, 1850 [1] occur from the intertidal to the sublittoral, inhabiting sand with shell or reef fragments, sandy mud, and mud [2-5], where they are selective deposit feeders and are an important food source for demersal species (e.g., blue crabs and juvenile cods) [6-8]. The species of this genus have relatively large bodies (ca. 50-300 mm long and 2-10 mm wide) and are easier to spot in the field. However, their diversity has not been correctly quantified to date [2-5]. The genus was first reported by Grube [9] based on Dasymallus caducus Grube, 1846 from the Mediterranean Sea. Grube [1] later changed Dasymallus to Dasybranchus without justification. Later, Eisig [10] redescribed the genus as having 14 thoracic segments (one achaetigerous peristomium and 13 chaetigers with capillary chaetae only), abdominal segments with only hooded hooks, and branchial tufts on the mid and posterior body. More recently, the genus was defined by Green [3] based on the genital pores in the thorax/abdomen transition, the unexpanded parapodial lobes of the abdominal segments, and the denticulation of the abdominal hooks. We follow this generic definition in the present study.

The ambiguous taxonomic boundaries and the poor descriptions of some species have caused taxonomic confusion within the genus [3,5]. For instance, Dasybranchus carneus Grube, 1870 [4] and Dasybranchus rectus Treadwell, 1901 [11] have only 12 thoracic chaetigers, which do not match the current definition, while the lack of essential information in their original descriptions prevents the reexamination of their placement at genus level. Furthermore, the features of the abdominal hooded hooks of D. caducus (the type species) differ between published records [3], and the description of D. microchaetus (Schmarda, 1861) [12] from Sry Lanka has not been improved since the poor original description. 
Although Dasybranchus has occasionally been mentioned in ecological studies, the only known report of a species of the genus in Korean waters, D. caducus, was based on a brief taxonomic description including two illustrations of the overall body shape and the abdominal hooded hooks [13]. Therefore, the purpose of this study was to assess the taxonomic status of the species of Dasybranchus existing in Korean waters based on both morphological and molecular features, as well as to compare them with their closest congeners. Additionally, we are also providing a dichotomous key for all known species of the genus.

\section{Materials and Methods}

Sublittoral samples were collected near Geojedo (South Korea) using a $0.05 \mathrm{~m}^{2}$ Van Veen grab (Figure 1 and Table 1). Sediments were elutriated over a $1 \mathrm{~mm}$ sieve, and the retained organisms were fixed in 10\% neutral buffered formalin and latter preserved in 95\% ethanol in the laboratory. Morphological identifications were done under a zoom stereomicroscope (SMZ745T, Nikon, Tokyo, Japan). Line drawings were created using a differential interference contrast microscope (Eclipse Ci-L, Nikon, Tokyo, Japan) with a drawing tube and digital pen display (Cintiq 22HD, Wacom, Kazo, Japan). Methyl green staining patterns (MGSP) were described and photographed. The specimens were bathed in a saturated solution of methyl green and 70\% ethanol for a minimum of one minute, and the MGSP was determined after placing them into clean $70 \%$ ethanol for one minute. Scanning electron microscopy (SEM) observations were performed as described by Jeong et al. [14]. Type materials were deposited at the Marine Biodiversity Institute of Korea (MABIK), Seocheon, Korea.

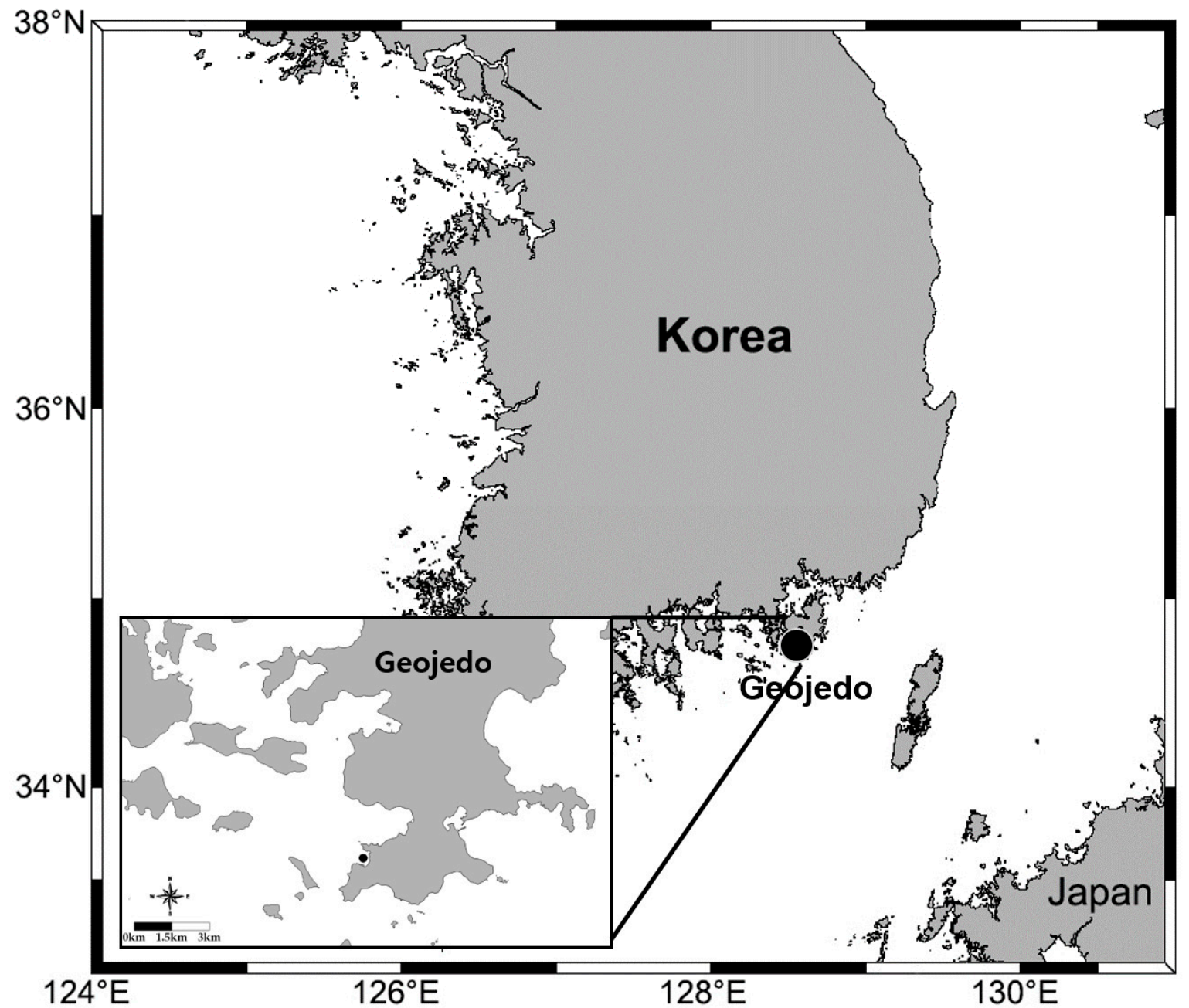

Figure 1. Map of study area showing type locality of D. geojedoensis sp. nov. 
Table 1. List of sampling localities, species name, specimen type, Marine Biodiversity Institute of Korea (MABIK) collection numbers, and GenBank accession numbers.

\begin{tabular}{|c|c|c|c|c|c|c|c|}
\hline \multicolumn{2}{|c|}{ Location } & \multirow{2}{*}{$\begin{array}{l}\text { Latitude/ } \\
\text { Longitude }\end{array}$} & \multirow{2}{*}{ Species } & \multirow{2}{*}{ Type } & \multirow{2}{*}{$\begin{array}{l}\text { Collection } \\
\text { Numbers }\end{array}$} & \multicolumn{2}{|c|}{ Accession Numbers } \\
\hline Nation & District & & & & & mtCOI & Histone $\mathrm{H} 3$ \\
\hline Korea & Geojedo & $\begin{array}{l}34^{\circ} 43.08^{\prime} \mathrm{N} \\
128^{\circ} 35.13^{\prime} \mathrm{E}\end{array}$ & $\begin{array}{l}\text { D. geojedoensis } \\
\text { sp. nov. }\end{array}$ & $\begin{array}{l}\text { Holotype } \\
\text { Paratype } \\
\text { Paratype }\end{array}$ & $\begin{array}{l}\text { NA00141494 } \\
\text { NA00141495 } \\
\text { NA00141496 }\end{array}$ & $\begin{array}{l}\text { MT513740 } \\
\text { MT513741 }\end{array}$ & $\begin{array}{l}\text { MT513742 } \\
\text { MT513743 }\end{array}$ \\
\hline
\end{tabular}

To extract genomic DNA from preserved specimens, $1.5 \mathrm{~mL}$ centrifuge tubes containing $90 \mu \mathrm{L}$ of $10 \%$ Chelex suspension (Bio-Rad Laboratories Inc., Hercules, CA, USA), $10 \mu \mathrm{L}$ of Proteinase $\mathrm{K}(10 \mathrm{mg} / \mathrm{mL}$, iNtRON Biotechnology, Inc., Daejeon, Korea), and dissected tissues (about $1 \mathrm{~mm}$ in diameter) were incubated at $56^{\circ} \mathrm{C}$, for $12 \mathrm{~h}$. Polymerase chain reactions (PCR) were performed on a PCR thermal cycler (TP600, Takara Co., Kyoto, Japan). To verify the genetic features of the Korean specimens, partial sequences of mitochondrial (mtCOI) and nuclear (histone H3) genes were used. The primer pair used for the mtCOI gene was polyLCO (5'-GAYTATWTTCAACAAATCATAAA GATATTGG-3') and polyHCO (5'-TAMACTTCWGGGTGACCAAARAATCA-3') [15]; for the histone H3 gene, it was H3F (5'-ATGGCTCGTACCAAGCAGACVGC-3') and H3R (5'-ATATCCTTRGGCATRATRGTGAC- $3^{\prime}$ ) [16]. The PCR mixtures contained $17 \mu \mathrm{L}$ of deionized water, $1 \mu \mathrm{L}$ of each primer $(10 \mu \mathrm{M})$, and $1 \mu \mathrm{L}$ of DNA template and PCR premix ( $20 \mu \mathrm{L}$, Bioneer Co., Daejeon, Korea). The temperature profile was as follows: $94{ }^{\circ} \mathrm{C} / 300 \mathrm{~s}\left(94{ }^{\circ} \mathrm{C} / 45 \mathrm{~s}, 46{ }^{\circ} \mathrm{C} / 45 \mathrm{~s}\right.$, and $\left.72{ }^{\circ} \mathrm{C} / 45 \mathrm{~s}\right) * 40$ cycles at $72{ }^{\circ} \mathrm{C} / 420 \mathrm{~s}$ for mtCOI; and $94{ }^{\circ} \mathrm{C} / 180 \mathrm{~s}$ $\left(94{ }^{\circ} \mathrm{C} / 45 \mathrm{~s}, 50{ }^{\circ} \mathrm{C} / 60 \mathrm{~s}\right.$, and $\left.72{ }^{\circ} \mathrm{C} / 60 \mathrm{~s}\right) * 35$ cycles at $72{ }^{\circ} \mathrm{C} / 420 \mathrm{~s}$ for histone H3. Purification and sequencing of the obtained PCR products were performed at the Macrogen Inc. facilities (Seoul, Korea). The sizes of obtained sequences for mtCOI and histone $\mathrm{H} 3$ were 510 and 333 base pair, respectively. The partial sequences of the Korean specimens were edited using Chromas software version 2.3 (Technelysium Pty Ltd., Brisbane, Australia) and were aligned with the sequences available in the public database (http://www.ncbi.nlm.nih.gov/Genbank) using the Molecular Evolutionary Genetics Analysis (MEGA) software version 7.0 [17]. The aligned sequences were used as datasets to generate genetic distance estimates using Kimura's two-parameter (K2P) model [18]. On the basis of the K2P distances, intra- and interspecific genetic differences among the examined taxa were calculated.

\section{Results}

\subsection{Systematics}

Family Capitellidae Grube, 1862 [19]

Genus Dasybranchus Grube, 1850 [1]

Type species Dasybranchus caducus (Grube, 1846)

\subsection{Generic Diagnosis}

Prostomium rounded or conical, palpode, and eyespots present or absent. Thorax with 14 segments, i.e., one achaetous peristomium and 13 segments with capillary chaetae only. Chaetiger 1 biramous. Abdominal chaetigers with hooded hooks only. Branchiae retractile as simple filaments or branched tufts arising from superior edge of neuropodia on median and posterior segments. Genital pores beginning on posterior end of thorax. Lateral organs present on thorax and abdomen.

Dasybranchus geojedoensis sp. nov.

Figures 2A-D and 3A-F. 

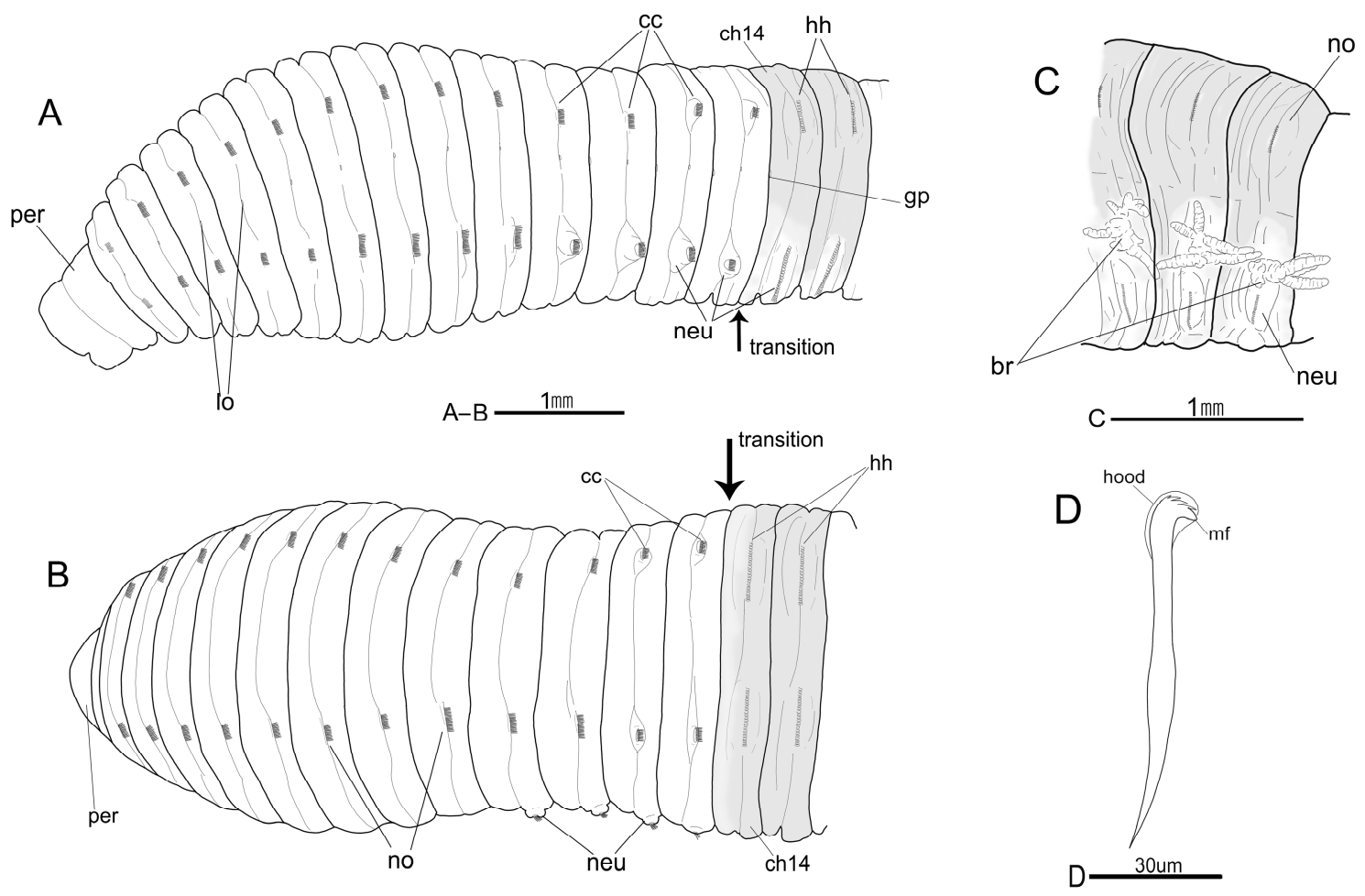

Figure 2. Dasybranchus geojedoensis sp. nov. (shadings indicate methyl green staining patterns (MGSP)). (A) Anterior end, left lateral view; (B) Same, dorsal view; (C) Abdominal chaetigers 64-66, left lateral view; (D) Abdominal hooded hook, lateral view. Br, branchiae; cc, capillary chaetae; ch, chaetiger; gp, genital pore; hh, hooded hooks; lo, lateral organ; mf, main fang; neu, neuropod; no, notopod; per, peristomium.

\subsection{Material Examined}

Holotype: MABIKNA00141494 (incomplete, 84 chaetigers), sampled in Korea, Geojedo, $34^{\circ} 43.085^{\prime} \mathrm{N}, 128^{\circ} 35.131^{\prime} \mathrm{E}$; subtidal zone of fish port, $13.7 \mathrm{~m}$ depth; collected by Jae-Seong Yun, in April 2013. Paratypes as follows: two specimens, MABIKNA00141495 and MABIKNA00141496 (incomplete, 33-80 chaetigers), same locality, depth, date, and collector as holotype.

\subsection{Species Diagnosis}

Thoracic chaetigers 1-8 weakly tessellated. Abdominal hooks with four rows of teeth on the main fang; three teeth in basal row, six in second and third rows, and eleven in superior row. Genital pores in intersegmental furrows between chaetigers 10-11, 11-12, 12-13, and 13-14. Branchiae dendritic, retractile, beginning from abdominal chaetiger 47, each tuft consisting of 7-9 branches.

\subsection{Description}

Holotype about $30 \mathrm{~mm}$ long and $2.4 \mathrm{~mm}$ wide for 84 chaetigers (terminal part missing). Body elongate, dorsally round, ventrally flattened, widest in mid-thoracic chaetigers, light brown in alcohol.

Prostomium almost concealed by peristomium, with blunt tip; nuchal organs and eyespots not seen. Everted proboscis with numerous short papillae (Figure 3B). Peristomium achaetous, bi-annulated, narrower than following thoracic segments, two times longer than first thoracic chaetiger (Figures 2A,B and $3 \mathrm{~B}, \mathrm{C})$.

The thorax had 14 segments including one achaetous peristomium and 13 chaetigers (Figure 2A,B), all strongly biannulated, with distinct intra- and intersegmental furrows, intrasegmental furrows more developed in posterior segments; peristomium and chaetigers 1-8 very weakly tessellated; following 
segments smooth (Figures 2A,B and 3B). First chaetiger biramous (Figure 2A). Thoracic noto- and neuropodia with bi-limbated capillaries only; thoracic chaetigers with about 15-30 capillaries per fascicle (Figure 2A,B). Parapodia inserted at intrasegmental furrows; notopodial lobes in chaetigers 12-13, and neuropodial lobes in chaetigers 10-13, distinctly protruding above epidermis (Figures 2A,B and 3C). Notopodia dorso-lateral, neuropodia lateral (Figure 2A,B). Lateral organ oval, inserted at intrasegmental furrows between noto- and neuropodia in all chaetigers (Figure 2A). Genital pores inserted at intersegmental furrows between chaetigers 10-11, 11-12, 12-13, and 13-14 (Figure 2A).
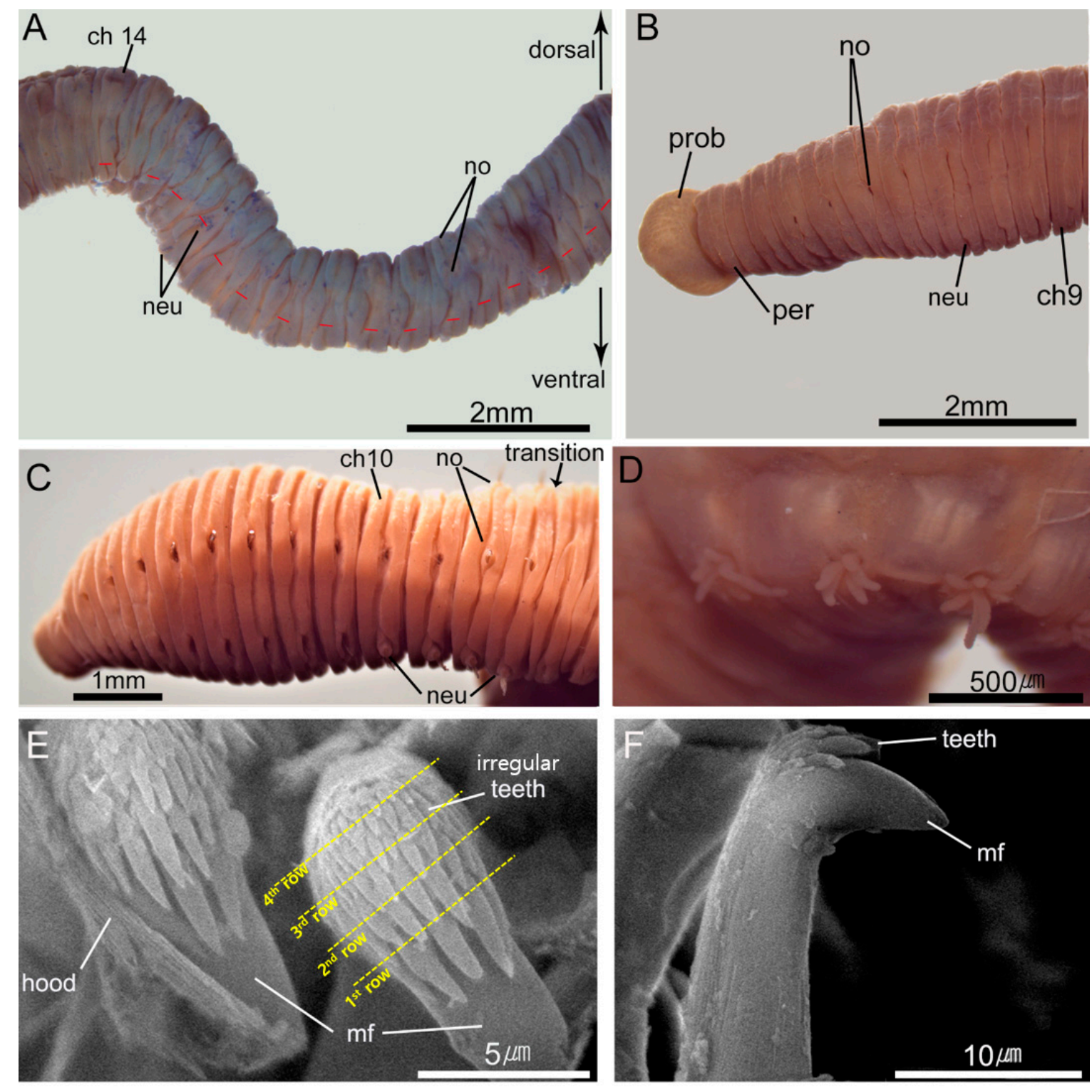

Figure 3. Dasybranchus geojedoensis sp. nov. (A) Anterior abdominal segments, left lateral view (red lines indicate dorsal edge of neuropodial chaetal fascicles, NA00141495); (B) Anterior thoracic segments with proboscis, left lateral view (NA00141495); (C) Anterior end, left lateral view (showing protruded parapodial lobes on chaetigers 10-13, NA00141494); (D) Abdominal branchiae, left lateral view (NA00141494); (E) Abdominal hooded hooks in frontal view; (F) Same, lateral view. ch, chaetiger; $\mathrm{mf}$, main fang; neu, neuropodium; no, notopodium; per, peristomium; prob, proboscis.

Transition between thorax and abdomen clearly distinct (Figures 2A,B and 3C). First abdominal segments tri- or multi-annulated, with only hooded hooks and parapodial lobes well separated from each other, weakly inflated above epidermis; neuropodial lobes longitudinally more expanded than 
notopodial lobes (Figures 2A,B and 3C). Abdominal notopodia clearly separated dorsally, dorsolateral, with 45-50 hooded hooks per fascicle (Figure 2A,B). Abdominal neuropodia separated by ventral furrow, lateroventral, with 90-110 hooded hooks per fascicle (Figure 2A). Hooded hooks with distinct node on shaft, main fang extending slightly beyond hoods, and four rows of small teeth above the main fang; three teeth in the basal row, six teeth in the second and third row, and eleven teeth in the apical row; teeth on the main fang gradually smaller apically; teeth of apical row irregularly arranged and overlap each other (Figures 2D and 3E,F). Branchiae dendritic, retractile, beginning from abdominal chaetiger 47; each tuft consisting of 7-9 branches (Figures 2C and 3D).

Methyl green staining distinct at most abdominal segments. Abdominal dorsum (including notopodial lobes and anterior ring of each abdominal segment) strongly stained with light blue (Figures $2 \mathrm{~A}-\mathrm{C}$ and $3 \mathrm{~A}$ ). Abdominal ventral part near neuropodial chaetal fascicles very weakly stained (Figures 2A,C and $3 \mathrm{~A}$ ).

\subsection{Etymology}

The specific epithet refers to the type locality, Geojedo.

\subsection{Distribution and Ecology}

Dasybranchus geojedoensis sp. nov. is only known from the type locality on the southeastern Korea; however, increased sample collection from other coastal areas could extend its distribution range. The average salinity, dissolved oxygen, and temperature of the bottom water layer was $33 \mathrm{PSU}, 8 \mathrm{mg} / \mathrm{L}$, and $12.5^{\circ} \mathrm{C}$, respectively. All obtained specimens were adult.

\subsection{Remarks}

Dasybranchus geojedoensis sp. nov. most closely resembled, Dasybranchus bipartitus (Schmarda, 1861) in the absence of distinct prostomial eyespots, the distinct gaps between notopodial lobes in the anterior abdominal segments, the position of the abdominal segments with branchiae, and the number of branchiae per fascicle (Table 2). However, the species clearly differ in the number of chaetigers with genital pores (10-14 in D. geojedoensis vs. 9-15 in D. bipartitus), the range of tessellated thoracic chaetigers (1-5 in D. geojedoensis vs. all in D. bipartitus), and the different denticulation of the abdominal hooks (Table 2). Additionally, the thoracic lateral organs are indistinct in D. bipartitus [20] and distinct in all thoracic segments in D. geojedoensis (Figure 2A). The clearly protruding parapodial lobes in the final thoracic chaetigers are a unique feature of D. geojedoensis (Figures 2A and 3C). Dasybranchus geojedoensis is easily distinguished from the $D$. caducus by the different segmental origin of the branchiae, the positions of the tessellated thoracic segments and the genital pores, and the denticulation of the abdominal hooded hooks (Table 2).

The MGSP can only be compared with that of D. eisigi Green, 2002 from Thailand, which showed distinct staining patterns in the prostomium (dark green), chaetigers 1-14 (green), chaetigers 15-18 (dark green), and the remaining abdominal segments (dark green in the ventral portion). Conversely, our new Korean species described in this study shows distinct staining only on the dorsum of the abdominal segments (Figure 3A and Table 2). 
Table 2. Summary of the main morphological characters for a comparison of Dasybranchus geojedoensis sp. nov. with the closely related species. Ch, chaetigers.

\begin{tabular}{|c|c|c|c|c|c|c|c|}
\hline Species & $\begin{array}{l}\text { Tessellated } \\
\text { Segments }\end{array}$ & $\begin{array}{c}\text { Genital } \\
\text { Pores }\end{array}$ & $\begin{array}{c}\text { Denticulation } \\
\text { of Hooded } \\
\text { Hooks }\end{array}$ & $\begin{array}{l}\text { Branchiae } \\
\text { (Number) }\end{array}$ & MGSP & $\begin{array}{c}\text { Habitat (Type } \\
\text { Locality) }\end{array}$ & References \\
\hline $\begin{array}{l}\text { D. geojedoensis } \\
\text { sp. nov. }\end{array}$ & Ch 1-5 & $\begin{array}{l}\text { Between } \\
\text { Ch } 10-14\end{array}$ & $\begin{array}{c}>26 \text { teeth in } 4 \\
\text { rows }(3 / 6 / 6 /> \\
11)\end{array}$ & $\begin{array}{c}\text { from } 47 \text { th } \\
\text { abdominal } \\
\text { chaetiger } \\
(7-9)\end{array}$ & $\begin{array}{l}\text { Dorsum of } \\
\text { abdomen } \\
\text { stained light } \\
\text { blue }\end{array}$ & $\begin{array}{l}\text { Subtidal, } 13 \mathrm{~m} \\
\text { depth, sandy } \\
\text { mud (southern } \\
\text { Korea) }\end{array}$ & This study \\
\hline D. bipartitus & Ch 1-13 & $\begin{array}{l}\text { Between } \\
\text { Ch 9-15 }\end{array}$ & $\begin{array}{c}>17 \text { teeth in } 3 \\
\text { rows } \\
(1-4 / 4-8 / ?)\end{array}$ & $\begin{array}{l}\text { from 40th } \\
\text { abdominal } \\
\text { chaetiger } \\
(2-13)\end{array}$ & Not examined & $\begin{array}{c}\text { Unknown } \\
\text { (South Africa) }\end{array}$ & {$[9,12,20]$} \\
\hline D. caducus & Ch 1-9 & $\begin{array}{l}\text { Between } \\
\text { Ch 12-15 }\end{array}$ & $\begin{array}{l}3-24 \text { teeth in } \\
1-3 \text { row }(\mathrm{s}) ; \\
\text { reexamination } \\
\text { required }\end{array}$ & $\begin{array}{l}\text { from } 20 \text { th } \\
\text { abdominal } \\
\text { chaetiger } \\
\quad(>20)\end{array}$ & Not examined & $\begin{array}{l}\text { Sandy mud } \\
\text { (Mediterranean } \\
\text { Sea) }\end{array}$ & {$[2,3]$} \\
\hline D. eisigi & Absent & $\begin{array}{l}\text { Between } \\
\text { Ch 11-15 }\end{array}$ & $\begin{array}{c}7 \text { teeth in } 2 \\
\text { rows }(4 / 3)\end{array}$ & $\begin{array}{c}\text { Not } \\
\text { examined }\end{array}$ & $\begin{array}{c}\text { Ch 1-14 } \\
\text { stained green, } \\
\text { Ch } 15-18 \text { and } \\
\text { venter of Ch } \\
\text { 19-21 stained } \\
\text { dark green }\end{array}$ & $\begin{array}{l}\text { Subtidal, } 21 \mathrm{~m} \\
\text { depth, sand } \\
\text { with shell } \\
\text { fragments } \\
\text { (Thailand) }\end{array}$ & {$[3]$} \\
\hline
\end{tabular}

\subsection{Molecular Comparison}

Genetic differences for the mtCOI (MT513740-MT513741) and histone H3 (MT513742-MT513743) genes between the two examined Korean specimens were not detected. According the mtCOI, D. geojedoensis showed a $52 \%$ of genetic distance from an undescribed species of Dasybranchus (EU835658) from Australia.

\section{Discussion}

According to the most recent taxonomic studies on the species of Dasybranchus, morphological details of the eyes, tessellated thoracic segments, anterior abdominal parapodia, lateral organs, genital pores, hooded hooks, and branchiae are crucial characteristics [3,5,21]. Among them, the position of the parapodial lobes in the anterior abdomen, the position of segments with genital pores or branchiae, and the degree of development of lateral organs are the most diagnostic characteristics to distinguish and describe a new species. However, some of them are incompletely reported in D. microchaetus, $D$. serratus, $D$. carneus, and D. rectus. The latter two are even ambiguous at the genus level and differ also in chaetal arrangement. Dasybranchus carneus has 12 thoracic chaetigers with only capillaries in both parapodia, and lacks chaetae in the second segment (i.e., first chaetiger) [4], while D. rectus has capillary chaetae on thoracic segments $2-13$ (i.e., chaetigers 1-12) [11] unlike other congeneric species, which have capillaries on the first 13 chaetigers. To clarify the taxonomic relationships and the boundaries of this genus, a re-examination of these incomplete and ambiguous species would be necessary.

Our study provides a detailed morphological description of $D$. geojedoensis $\mathrm{sp}$. nov., including the MGSP. With a single exception, the MGSP of the species of Dasybranchus are mostly unknown. Staining patterns proved to be useful to distinguish species in various capitellid genera, even when dealing with fragmented specimens [3,22-24]. Our study confirms the differences in the MGSP between the two species of Dasybranchus, suggesting that it can be also used as an additional character in identification keys for the species of this genus.

Our molecular comparison result (mean K2P distance, 52\%) exceeds the commonly reported interspecific difference of the mtCOI (13-23\%) among capitellid species [14,22,25]. Although the mtCOI and $\mathrm{H} 3$ genes are useful for distinguishing taxa at the species level, we were not able to locate any other comparable sequences for recognized species of Dasybranchus in public databases. In addition, we 
were not able to obtain sequences from other genetic loci (i.e., $18 \mathrm{~S}$ rRNA or $28 \mathrm{~S}$ rRNA) that could have been effective in determining the phylogenetic position of the new Korean species, and therefore our molecular result provides only limited information. To more accurately resolve relationships within Dasybranchus, both broader taxon sampling and additional genetic markers would be necessary.

The key to species of Dasybranchus (except D. microchaetus and D. serratus) is as follows:

1 Thorax with 12 chaetigers

- Thorax with 13 chaetigers

2 Prostomium without eyespots; all thoracic segments tessellated

- Prostomium with eyespots; anterior thoracic segments tessellated

3 Prostomium with eyespots; all thoracic segments smooth,

D. carneus Grube, 1870

- Prostomium without eyespots

D. rectus Treadwell, 1901

4 Anterior abdominal notopodia dorsally far apart from each other $\quad 5$

- Anterior abdominal notopodia dorsally close to each other $\quad 8$

5 Branchiae beginning from near abdominal chaetigers 10-20 6

- Branchiae beginning from near abdominal chaetigers 40-50 $\quad 7$

6 Each branchial tuft with 15-20 filaments; genital pores between chaetigers 12-15

- Each branchial tuft with 5-30 filaments; genital pores between chaetigers 9-25

D. caducus (Grube, 1846)

7 Anterior thoracic segments weakly tessellated; genital pores between chaetigers 10-14

D. platyceps Hartman, 1947

- All thoracic segments tessellated; genital pores between chaetigers 9-15

D. geojedoensis sp. nov.

8 All thoracic segments tessellated

D. bipartitus (Schmarda, 1861)

- All thoracic segments smooth

9 Abdominal hooded hooks with teeth in three to four rows above main fang; each branchial tuft with 10-20 filaments

D. gajolae Eisig, 1887

- Abdominal hooded hooks with six teeth in two rows above main fang; each branchial tuft with 2-10 filaments

D. parplatyceps Kudenov, 1975

- Abdominal hooded hooks with three teeth in one row above main fang; each branchial tuft with 30 filaments

D. lumbricoides Grube, 1878 [27]

10 Abdominal hooded hooks with seven teeth in two rows above main fang

D. eisigi Green, 2002

- Abdominal hooded hooks with three teeth in two to three rows above main fang; each branchial tuft with 2-3 filaments

D. glabrus Moore, 1909 [28].

Author Contributions: Conceptualization: M.-K.J. and H.Y.S.; methodology: M.-K.J. and H.Y.S.; formal analysis: M.-K.J.; investigation: M.-K.J.; visualization: M.-K.J.; resources: M.-K.J. and H.Y.S.; supervision: H.Y.S. writing—original draft preparation: M.-K.J.; writing—review and editing: M.-K.J. and H.Y.S. All authors have read and agreed to the published version of the manuscript.

Funding: This research was a part of the project titled "Research center for fishery resource management based on the information and communication technology" (2020, grant number 20183084), funded by the Ministry of Oceans and Fisheries, Korea.

Acknowledgments: We thank the anonymous reviewers and the editor who made constructive and invaluable suggestions and comments.

Conflicts of Interest: The authors declare no conflict of interest. 


\section{References}

1. Grube, A.E. Die Familien der Anneliden.; Archiv für Naturgeschichte: Berlin, Germany, 1850; pp. $249-364$.

2. Day, J.H. A Monograph on the Polychaeta of Southern Africa; Part II; British Museum (Natural History): London, UK, 1967; pp. 1-450.

3. Green, K. Capitellidae (Polychaeta) from the Andaman Sea. Phuket Mar. Biol. Cent. Spec. Publ. 2002, 24, 249-343.

4. Grube, E. Beschreibungen neuer oder weniger bekannter von Hrn. Ehrenberg gesammelter Anneliden des rothen Meeres. Mon. K. Preuss. Akad. Wiss. Berl. 1870, 1869, 484-521.

5. Hartman, O. Polychaetous annelids. Part VII. Capitellidae. Allan Hancock Pac. Exped. 1947, 10, $391-481$.

6. Armstrong, M. The predator-prey relationships of Irish Sea poor-cod (Trisopterus minutus L.), pouting (Trisopterus luscus L.) and cod (Gadus morhua L.). Ices J. Mar. Sci. 1982, 40, 135-152. [CrossRef]

7. Fauchald, K.; Jumars, P.A. The diet of worms: A study of polychaete feeding guilds. Oceanogr. Mar. Biol. Annu. Rev. 1979, 17, 193-284.

8. Stoner, A.W.; Buchanan, B.A. Ontogeny and overlap in the diets of four tropical Callinectes species. Bull. Mar. Sci. 1990, 46, 3-12.

9. Grube, A.E. Beschreibung neuer oder wenig bekannter Anneliden. Beitrag: Canephorus, Ammochares, Dasymallus, Scalis-Arten. Arch. Nat. Berl. 1846, 12, 161-171.

10. Eisig, H. Monographie der Capitelliden des Golfes von Neapel. Fauna Flora Golf. Neapel 1887, 16, 1-906.

11. Treadwell, A.L. The polychaetous annelids of Porto Rico. Bull. U. S. Fish Comm. 1901, 20, 181-210.

12. Schmarda, L.K. Neue Wirbellose Thiere Beobachtet und Gesammelt auf einer Reise um die Erde 1853 bis 1857; Wilh. Engelmann: Leipzig, Germany, 1861; Volume 3, pp. 1-164.

13. Paik, E.I. New records of five polychaetous annelids species in Korea. Korean J. Fish. Aquat. Sci. 1979, 12, 35-39.

14. Jeong, M.-K.; Wi, J.H.; Suh, H.-L. A reassessment of Capitella species (Polychaeta: Capitellidae) from Korean coastal waters, with morphological and molecular evidence. Mar. Biodivers. 2017, 48, 1969-1978. [CrossRef]

15. Carr, C.M.; Hardy, S.M.; Brown, T.M.; Macdonald, T.A.; Hebert, P.D. A tri-oceanic perspective: DNA barcoding reveals geographic structure and cryptic diversity in Canadian polychaetes. PLOS ONE 2011, 6, e22232. [CrossRef] [PubMed]

16. Colgan, D.; McLauchlan, A.; Wilson, G.; Livingston, S.; Edgecombe, G.; Macaranas, J.; Cassis, G.; Gray, M. Histone H3 and U2 snRNA DNA sequences and arthropod molecular evolution. Aust. J. Zool. 1998, 46, 419-437. [CrossRef]

17. Kumar, S.; Stecher, G.; Tamura, K. MEGA7: Molecular Evolutionary Genetics Analysis version 7.0 for bigger datasets. Mol. Biol. Evol. 2016, 33, 1870-1874. [CrossRef] [PubMed]

18. Kimura, M. A simple method for estimating evolutionary rates of base substitutions through comparative studies of nucleotide sequences. J. Mol. Evol. 1980, 16, 111-120. [CrossRef]

19. Grube, A.E. Noch ein Wort über die Capitellen und ihre Stelle im Systeme der Anneliden; Archiv fur Naturgeschichte: Berlin, Germany, 1862; pp. 366-378.

20. Day, J.H. The Polychaeta of South Africa. Part 3. Sedentary species from Cape shores and estuaries. Zool. J. Linn. Soc. 1955, 42, 407-452. [CrossRef]

21. Kudenov, J.D. Sedentary polychaetes from the Gulf of California, Mexico. J. Nat. Hist. 1975, 9, $205-231$. [CrossRef]

22. Jeong, M.K.; Soh, H.Y.; Suh, H.L. Three new species of Heteromastus (Annelida, Capitellidae) from Korean waters, with genetic evidence based on two gene markers. Zookeys 2019, 869, 1-18. [CrossRef]

23. Magalhães, W.F.; Bailey-Brock, J.H. Capitellidae Grube, 1862 (Annelida: Polychaeta) from the Hawaiian Islands with description of two new species. Zootaxa 2012, 3581, 1-52. [CrossRef]

24. Silva, C.; Amaral, A.C.Z. Scyphoproctus Gravier, 1904 (Annelida, Capitellidae): Description of three new species and relocation of Heteromastides Augener, 1914 in Scyphoproctus. Zootaxa 2019, 4560, 95-120. [CrossRef]

25. Silva, C.F.; Shimabukuro, M.; Alfaro-Lucas, J.M.; Fujiwara, Y.; Sumida, P.Y.; Amaral, A.C. A new Capitella polychaete worm (Annelida: Capitellidae) living inside whale bones in the abyssal South Atlantic. Deep Sea Res. Oceanogr. Res. Pap. 2016, 108, 23-31. [CrossRef] 
26. Ehlers, E. Reports on the Results of Dredging, Under the Direction of L.F. Pourtalès, During the Years 1868-1870, and of Alexander Agassiz in the Gulf of Mexico (1877-78) and in the Caribbean Sea (1878-79), in the U.S. Coast Survey Steamer "Blake", Lieut.-Com. C.D. Sigsbee, U.S.N., and Commander J.R. Bartlett, U.S.N., Commanding: Report on the Annelids; Memoirs of the Museum of Comparative Zoology at Harvard College: Cambridge, MA, USA, 1887; pp. 1-335.

27. Grube, A.E. Annulata Semperiana. Beiträge zur Kenntnis der Annelidenfauna der Philippine; Kessinger Publishing LLC: Whitefish, MT, USA, 1878; pp. 1-300.

28. Moore, J.P. Polychaetous annelids from Monterey Bay and San Diego, California. Proc. Acad. Natl. Sci. Phila. $1909,61,235-295$. 